\title{
BM] Global Health Caffeine for the care of preterm infants in sub-Saharan Africa: a missed opportunity?
}

\author{
Helen M Nabwera (D) , ${ }^{1,2}$ Osayame A Ekhaguere (D) , ${ }^{3}$ Haresh Kirpalani, ${ }^{4}$ \\ Kathy Burgoine (D) , ${ }^{5}$ Chinyere V Ezeaka, ${ }^{6}$ Walter Otieno, ${ }^{7,8}$ Stephen J Allen, ${ }^{1,9}$ \\ Nicholas D Embleton, ${ }^{10,11}$ The Neonatal Nutrition Network (NeoNuNet)
}

To cite: Nabwera HM, Ekhaguere $\mathrm{OA}$, Kirpalani $\mathrm{H}$, et al. Caffeine for the care of preterm infants in subSaharan Africa: a missed opportunity?BMJ Global Health 2021;6:e007682. doi:10.1136/ bmjgh-2021-007682

Handling editor Seye Abimbola

- Additional supplemental material is published online only. To view, please visit the journal online (http://dx.doi.org/10. 1136/bmjgh-2021-007682)

Received 9 October 2021 Accepted 24 November 2021

Check for updates

C Author(s) (or their employer(s)) 2021. Re-use permitted under CC BY-NC. No commercial re-use. See rights and permissions. Published by BMJ.

For numbered affiliations see end of article.

Correspondence to Dr Helen M Nabwera; Helen.Nabwera@Istmed.ac.uk

\section{BACKGROUND}

In 2019, 2.4million neonates (infants $<28$ days of age) died globally. Of these, over $80 \%$ were preterm infants ( $<37$ weeks gestation), with the majority born in low-income and middle-income countries. ${ }^{1}$ Complications of preterm birth, largely from respiratory distress syndrome due to surfactant deficiency, pneumonia or apnoea of prematurity (AOP), are now the leading cause of under 5 mortality globally. ${ }^{1}$ These conditions are frequently fatal in the absence of effective ventilatory support which is commonplace in neonatal units across sub-Saharan Africa. Although the global neonatal mortality rate (NMR) has halved over the past three decades, significant regional disparities remain. These correlate with World Bank and International Monetary Fund estimates of the proportion of the population living on less than US $\$ 1.90 \mathrm{a}$ day, with the majority of poorer countries being in sub-Saharan Africa. ${ }^{12}$ As the region with the highest NMR of 27 per 1000 live births, it is estimated that a baby born in in sub-Saharan Africa is 10 times more likely to die than one born in a high income country. ${ }^{1}$ Countries in sub-Saharan Africa are unlikely to meet the global target of no more than 12 newborn deaths per 1000 live births by 2030. ${ }^{3}$ In 2017, 75 countries (almost half from sub-Saharan Africa) signed up to the 'Every Newborn Action Plan' that has strategic global and national actions and milestones to address gaps in maternal and newborn care. ${ }^{4}$ This ambitious commitment requires evidencebased interventions ${ }^{5}$ and innovative strategies to improve neonatal survival and longer-term outcomes.

\section{CAFFEINE CITRATE: AN EVIDENCE-BASED THERAPY USED WIDELY IN HIGH-INCOME AND MIDDLE-INCOME COUNTRIES}

AOP, a common complication of preterm birth, would likely be better prevented and treated in low-income countries if caffeine citrate was more
Summary box

- The majority of the estimated 15 million preterm infants ( $<37$ weeks gestation) delivered worldwide are born in low-income and middle-income countries.

- In sub-Saharan Africa, nearly half of very preterm infants $(<32$ weeks gestation) die in the first 28 days and sparse data indicates neurodevelopmental impairment in many of those who survive.

- Apnoea of prematurity (AOP), a common complication of very preterm infants, contributes significantly to mortality and morbidity.

- In resource-limited settings, aminophylline is used for prevention and treatment of AOP but concerns remain about its safety and efficacy given limited therapeutic drug monitoring.

- Caffeine citrate, the drug of choice for the prevention and treatment of $\mathrm{AOP}$ in high-income countries, is either unavailable or prohibitively expensive in sub-Saharan Africa.

- Use of caffeine citrate for AOP in sub-Saharan Africa could significantly reduce mortality and morbidity in very preterm infants.

widely available. ${ }^{1}{ }^{6}$ High-quality randomised controlled trial data, predominantly from highincome countries, strongly support the use of caffeine citrate to prevent adverse outcomes of prematurity and treat $\mathrm{AOP}^{7}$ (table 1).

Four decades of use in high-income countries confirms the low-risk profile of caffeine citrate and its ease of administra$\operatorname{tion}^{78}$ (online supplemental table 1). It is one of the most widely prescribed drugs in neonatal units in high-income settings. ${ }^{9}$ Although WHO included caffeine citrate in the Model list of Essential Medicines for Children-'Medicines administered to the neonate' in 2019 (caffeine citrate for injection and oral formulation $-20 \mathrm{mg} / \mathrm{mL}$, equivalent to $10 \mathrm{mg}$ caffeine base $/ \mathrm{mL}),{ }^{10}$ to our knowledge, it is not in widespread use in sub-Saharan Africa. 
Table 1 Summary of findings from research studies of caffeine citrate in preterm infants

\begin{tabular}{lll}
\hline Infant population & Benefits & Source of evidence \\
\hline Birth weight $500-1250 \mathrm{~g}$ & $\begin{array}{l}\text { 1. } \begin{array}{l}\text { Reduced risk of neurodisability at 18-21 } \\
\text { months }\end{array} \\
\begin{array}{l}\text { 2. Improved cognitive development at 18-21 } \\
\text { months }\end{array}\end{array}$ & High-income countries \\
Infants $\leq 34$ weeks gestation & $\begin{array}{l}\text { 1. Reduction in apnoea (equivocal) } \\
\text { 2. Reduction in bronchopulmonary dysplasia } \\
\text { (chronic lung disease) }\end{array}$ & $\begin{array}{l}\text { High-income and low-income and } \\
\text { middle-income countries }\end{array}$ \\
& $\begin{array}{l}\text { 3. Reduction in severe retinopathy of } \\
\text { prematurity }\end{array}$ & \\
\hline
\end{tabular}

\section{WHY IS CAFFEINE NOT USED IN SUB-SAHARAN AFRICA, AND WHAT ALTERNATIVES ARE AVAILABLE?}

Caffeine citrate is largely unavailable in sub-Saharan Africa due to its high cost. A 7-day course for a preterm infant could cost as much as US\$600 in Kenya, which would far exceed the monthly income of most families and prevents widespread access. ${ }^{11}$ The only available alternative is intravenous aminophylline, which to avert side effects, demands therapeutic drug monitoring $(\mathrm{TDM})^{12}$ (online supplemental table 2). An efficacy trial with 31 preterm infants in South Africa comparing oral caffeine citrate to intravenous aminophylline found caffeine as efficacious as aminophylline in treating AOP. Most importantly, caffeine use facilitated breastfeeding and was more practical requiring no TDM. ${ }^{13}$ This is consistent with studies in high-income settings showing advantages of caffeine over aminophylline. ${ }^{7}$ Finally, vital sign monitoring of small sick newborn infants to identify potentially life-threatening AOP is often not feasible due to shortages of neonatal nurses and monitoring equipment. Therefore, introducing a drug that is easy to administer with a low risk profile may be specifically relevant to this setting. ${ }^{14}$

In a recent survey of neonatologists in sub-Saharan Africa, 55 respondents from 13 countries noted that country-specific regulations hindered caffeine accessibility. This was compounded by monopoly of suppliers with unregulated and high prices. ${ }^{11}$ Ironically, many of these countries are coffee-producing countries. Generic drug usage allows for local manufacture of drugs, therefore, bypassing the logistical challenges and expenses of importing. However, this must be appropriately regulated to ensure quality control measures and avoiding counterfeit medicines. ${ }^{15}$ Such considerations raise the question of whether the costs of local production may exceed the current costs. Several neonatal units in highincome countries use locally prepared oral caffeine citrate formulations for neonatal care using stringent protocols and quality control measures because it is far cheaper than currently approved preparations (personal communication). To ensure sustainability, the WHO clinical recommendations for caffeine citrate use in neonatal care would require regulatory changes to allow national/ regional pharmacies in sub-Saharan Africa to prepare formulations for within-country use. Pilot studies to evaluate the feasibility and acceptability of implementing locally produced caffeine citrate for neonatal care in the sub-Saharan African context are currently underway and may provide key insights into the feasibility of this approach.

\section{The way forward}

To expedite the routine use of caffeine citrate in neonatal care in sub-Saharan Africa, we recommend these pragmatic steps:

- Conduct a multicentre randomised controlled trial to assess the efficacy and safety of caffeine citrate versus standard of care (either aminophylline or placebo depending on setting) for the prevention and/or treatment of AOP in sub-Saharan Africa.

- Begin discussions with in-country partners, industry and drug regulatory bodies to explore means of enhancing the safety, availability and affordability of caffeine citrate for neonatal care in sub-Saharan Africa.

The global community seeks to address inequities in neonatal mortality between well-resourced and poorly resourced countries. We highlight this key inequity in the availability of one among many essential medicines for neonatal care. We believe firmly that generating evidence on the efficacy and feasibility of caffeine citrate use in neonatal care in sub-Saharan Africa could lead to accelerated progress in improving the survival and long-term outcomes of preterm infants in this and other resourcelimited settings.

\section{Author affiliations}

${ }^{1}$ Clinical Sciences, Liverpool School of Tropical Medicine, Liverpool, UK ${ }^{2}$ Infectious Diseases, Alder Hey Children's Hospital, Liverpool, UK

${ }^{3}$ Neonatal-Perinatal Medicine, Indiana University Department of Pediatrics, Indianapolis, Indiana, USA

${ }^{4}$ Emeritus Department Pediatrics, McMaster University, Hamilton, Ontario, Canada

${ }^{5}$ Neonatal Unit, Mbale Regional Referral Hospital, Mbale, Uganda

${ }^{6}$ Paediatrics, Lagos University Teaching Hospital, Lagos, Nigeria

${ }^{7}$ Paediatrics, Maseno University, Maseno, Nyanza, Kenya

${ }^{8}$ Paediatrics, Jaramogi Oginga Odinga Teaching and Referral Hospital, Kisumu, Kenya

${ }^{9}$ Gastroenterology, Alder Hey Children's Hospital, Liverpool, UK

${ }^{10}$ Neonatal Medicine, Newcastle University, Newcastle upon Tyne, UK

${ }^{11}$ Neonatology, Newcastle Upon Tyne Hospitals NHS Trust, Newcastle Upon Tyne, UK

Acknowledgements We would like to thank our colleagues in the Neonatal Nutrition Network who shared their perspectives on caffeine citrate use in 
newborn care in sub-Saharan Africa. We also thank Zulfiqar Bhutta (Global Child Health, Hospital for Sick Children, Toronto and Aga Khan University, Karachi), Imti Choonaara (University of Nottingham), Danielle Ehret (University of Vermont), Jeff Horbar (University of Vermont), Lehana Thabane (McMaster University, Ontario) Bogale Worku (Addis Ababa University) and John Zupancic (Harvard University and Boston Children's Hospital) for their very useful insights on how to approach the challenge of evidence generation and access of caffeine citrate for newborn care in low-income and middle-income countries.

Collaborators Neonatal Nutrition Network members: Isa Abdulkadir (Ahmadu Bello University, Zaria, Nigeria); Ismaela Abubakar (Liverpool School of Tropical Medicine, Liverpool, UK); Abimbola E Akindolire (College of Medicine, University of Ibadan, Nigeria); Olusegun Akinyinka (College of Medicine, University of Ibadan, Nigeria); Stephen J Allen (Liverpool School of Tropical Medicine, Liverpool, UK); Pauline EA Andang'o (Maseno University, Kenya); Nana Brako (Greater Accra Regional Hospital, Ghana), Kathy Burgoine (Mbale Regional Referral Hospital, Uganda), Graham Devereux (Liverpool School of Tropical Medicine, Liverpool, UK); Chinyere Ezeaka (Lagos University Teaching Hospital, Nigeria); Beatrice N Ezenwa (Lagos University Teaching Hospital, Nigeria); Iretiola B Fajolu (Lagos University Teaching Hospital, Nigeria); Zainab 0 Imam (Lagos State University Teaching Hospital, Lagos, Nigeria); Kevin Mortimer (Liverpool School of Tropical Medicine, Liverpool, UK); Kunda Mutesu-Kapembwa (University Teaching Hospital, Lusaka, Zambia), Martha K Mwangome (KEMRI Wellcome Trust Research Programme, Kilifi, Kenya); Helen M Nabwera (Liverpool School of Tropical Medicine, Liverpool, UK); Grace M Nalwa (Jaramogi Oginga Odinga Teaching and Referral Hospital, Kisumu, Kenya \& Maseno University, Kenya); Walter Otieno (Jaramogi Oginga Odinga Teaching and Referral Hospital, Kisumu, Kenya \& Maseno University, Kenya); Alison W Talbert (KEMRI Wellcome Trust Research Programme, Kilifi, Kenya); Nicholas D Embleton (Newcastle University, Newcastle, UK); Olukemi 0 Tongo (College of Medicine, University of Ibadan, Nigeria); Dominic D Umoru (Maitama District Hospital, Abuja, Nigeria); Janneke van de Wijgert (University of Liverpool, Liverpool, UK); Melissa Gladstone (University of Liverpool, Liverpool, UK).

Contributors NDE, KB, SJA and HMN conceived the idea presented; all authors contributed to the conception and writing of the commentary. All authors read and approved the final manuscript.

Funding The authors have not declared a specific grant for this research from any funding agency in the public, commercial or not-for-profit sectors.

Competing interests None declared.

Patient consent for publication Not applicable.

Ethics approval This study does not involve human participants.

Provenance and peer review Not commissioned; externally peer reviewed.

No data was used for this commentary.

Supplemental material This content has been supplied by the author(s). It has not been vetted by BMJ Publishing Group Limited (BMJ) and may not have been peer-reviewed. Any opinions or recommendations discussed are solely those of the author(s) and are not endorsed by BMJ. BMJ disclaims all liability and responsibility arising from any reliance placed on the content. Where the content includes any translated material, BMJ does not warrant the accuracy and reliability of the translations (including but not limited to local regulations, clinical guidelines, terminology, drug names and drug dosages), and is not responsible for any error and/or omissions arising from translation and adaptation or otherwise.
Open access This is an open access article distributed in accordance with the Creative Commons Attribution Non Commercial (CC BY-NC 4.0) license, which permits others to distribute, remix, adapt, build upon this work non-commercially, and license their derivative works on different terms, provided the original work is properly cited, appropriate credit is given, any changes made indicated, and the use is non-commercial. See: http://creativecommons.org/licenses/by-nc/4.0/.

\section{ORCID iDs}

Helen M Nabwera http://orcid.org/0000-0003-1056-729X

Osayame A Ekhaguere http://orcid.org/0000-0002-8926-3709

Kathy Burgoine http://orcid.org/0000-0001-7975-745X

\section{REFERENCES}

1 WHO. World bank: levels and trends in chilld mortality. New York: UNICEF, 2020. https://www.who.int/publications/i/item/jme-2020edition

2 World Bank. Poverty, 2020. Available: https://www.worldbank.org/ en/topic/poverty [Accessed 07 Oct 2021].

3 United Nations. United nations sustainable development goals. Available: http://www.un.org/sustainabledevelopment/sustainabledevelopment-goals/ [Accessed 07 Oct 2021].

4 Countdown to 2030 Collaboration. Countdown to 2030: tracking progress towards universal coverage for reproductive, maternal, newborn, and child health. Lancet 2018;391:1538-48.

5 Bhutta ZA, Das JK, Bahl R, et al. Can available interventions end preventable deaths in mothers, newborn babies, and stillbirths, and at what cost? Lancet 2014;384:347-70.

6 Schmidt B. Caffeine editorial. Semin Fetal Neonatal Med 2020;25:101181.

7 Abdel-Hady H, Nasef N, Shabaan AE, et al. Caffeine therapy in preterm infants. World J Clin Pediatr 2015;4:81-93.

8 Moschino L, Zivanovic S, Hartley C, et al. Caffeine in preterm infants: where are we in 2020? ERJ Open Res 2020;6. doi:10.1183/23120541.00330-2019. [Epub ahead of print: 0203 2020].

9 Stark A, Smith PB, Hornik CP, et al. Medication use in the neonatal intensive care unit and changes from 2010 to 2018. J Pediatr 2021. doi:10.1016/j.jpeds.2021.08.075. [Epub ahead of print: 02 Sep 2021]

10 WHO. WHO model list of essential medicines for children - 7th list, 2019. Geneva: WHO, 2019

11 Ekhaguere OA, Ayede Al, Ezeaka CV. Is caffeine available and affordable in low and middle-income countries? a survey in subSaharan Africa. Semin Fetal Neonatal Med 2020;25:101182.

12 Mueni E, Opiyo N, English M. Caffeine for the management of apnea in preterm infants. Int Health 2009;1:190-5.

13 Schellack N, Gous AGS, Mawela PB. Caffeine versus aminophylline for the prevention of apnoea of prematurity in a teaching hospital in South Africa. South African Family Practice 2015;57:140-5.

14 Murphy GAV, Gathara D, Abuya N, et al. What capacity exists to provide essential inpatient care to small and sick newborns in a high mortality urban setting? - a cross-sectional study in Nairobi City County, Kenya. PLoS One 2018;13:e0196585.

15 Almuzaini T, Choonara I, Sammons H. Substandard and counterfeit medicines: a systematic review of the literature. BMJ Open 2013;3:e002923. 